\title{
The Development of Local Music in Southern Shandong Province under the background of Massive Open Online Course
}

\author{
Qingpeng Huang \\ College of Music and Dance, Zaozhuang University, Zaozhuang, Shandong Province \\ 277160 , China \\ musichqp@163.com
}

\begin{abstract}
Keywords: Massive open online course; Southern Shandong local music; Inheritance; Development
\end{abstract}

\begin{abstract}
The unstoppable development of massive open online courses has brought new opportunities and challenges to the teaching mode of higher music education in our country and the inheritance and development of local music in southern Shandong Province. In this context, the reform of the teaching mode of the local traditional music course in southern Shandong Province to improve the teaching quality provides an opportunity for popularizing the local traditional music in southern Shandong Province.
\end{abstract}

\section{Introduction}

The music of southern Shandong Province has a long history and is also an integral part of the excellent culture of the Chinese nation. Over the past several thousand years, it has shown the obvious epoch imprint and rich cultural and historical details in the southern part of Shandong Province. "Sitting straight on his chair, clasping the mandarin duck board with left hand and striking it up and down among the fingers, and then jingling the mandarin duck to give a crisp sound, holding a drumstick with right hand, holding his breath and beating the drum three or five times, boom-bang-bang-bang bang, starting to talk about long-lost Lunan Dagu, the word is clear, the voice is vigorous... "[1] Now, there are many excellent music cultures such as Lunan Dagu, the note of an era, have gradually disappeared behind the rich entertainment culture. But as a kind of traditional folk culture, we should ponder how to better inherit and develop Lunan Dagu.

An Overview of Massive Open Online Courses and Local Music in Southern Shandong Province. The full name of "Massive Open Online Course" is now referred as the acronym MOOC. Massive (Large scale) refers to the number of learners who can participate in a course Different from the traditional classroom courses, a MOOC can be easily accessible to thousands of people, tens of thousands, or even a number of 100,000 people, while the ordinary classroom can accommodate at most a few hundred people. The second letter "O" stands for Open, which means open teaching. The current education and teaching for learners, especially the higher education, has certain barriers and limitations, but massive open online course is different, as long as learners can have a computer to access the Internet, and have time for study, they can participate in online learning, regardless of gender, age and nationality. The third letter " $\mathrm{O}$ " stands for Online, which refers to learning through the network, sharing learning information and resources through the network, getting scriptures without travelling to the west, not being subject to space-time restrictions. Course refers to the educational form of "MOOC", which is the activity of teaching and learning by means of curriculum. Different from other online courses, "MOOC" is the teaching of "one course". However, most other online courses such as microlecture and video open courses focus on "one lesson".

The term "MOOC" has been determined or formed with a relatively fixed teaching model for a short time, but it has a long process of accumulation and gestation. The history of MOOC can be traced back to the early 16th century, when the development of printing technology and communication technology enabled the civilian class to have access to self-study of The Bible. 
Therefore, the religious aristocrats at that time did not enjoy the monopoly of the dissemination of Christian doctrine, thus gradually education could also be popularized. And then, after the development of distance education (including correspondence education, broadcasting education), electronic media education, computer teaching, and social media on the Internet, in 2007, a turning point, David Willie, professor at Utah State University, in the United States, as the first "Warrior" who dares to eat crabs in the field of online courses, developed a course of "Introduction to Open Education" by using Wiki technology, and publicized his lectures on education online which is free to the global access in 2008. In 2011, MOOC education opened a new chapter. Stanford University in the United States, and Sebastian Trent, a representative sample of professors,, developed courses such as "Introduction to Artificial Intelligence" by using audio-visual equipment

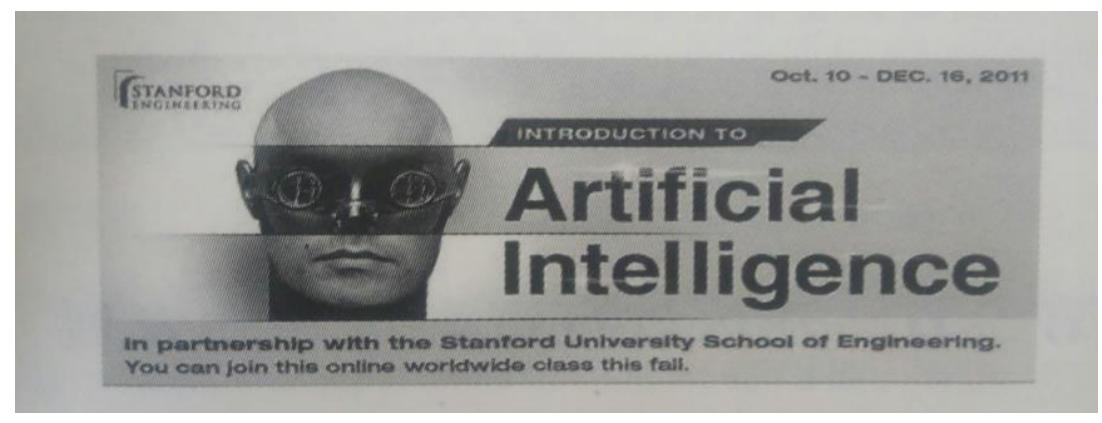

Figure 1. The network course

These courses were open to the world through the school's online learning website, the number of students enrolled in the course had soared since it was allowed to sign up, and by the time it was officially opened, the number of students enrolled in the course had topped 160,000. Due to the amazing effect of the class model, since 2012, many investment companies and technical research and development teams have joined forces to enter the field of education todevelop MOOC curriculum, develop platform and operate the related systems. So 2012 is called the first year of MOOC.

The local music of southern Shandong Province refers to the general name of folk songs, dances, folk operas, Quyi, instrumental music, ritual music and religious music rooted in southern Shandong Province, mainly including Jining, Heze, Zaozhuang, Linyi, Rizhao and other cities and counties, accounting for nearly $1 / 3$ of the total area of Shandong Province. Southern Shandong Province is a densely populated area with a population of $1 / 3$ of that of the province. Its economy has developed rapidly in recent years and has good development trend. The more representative folk songs are Lunan Haozi, folk custom songs, flower drum opera, children's songs, Minor Keys; dances include flower basket dance, lantern dance, lion dance, Zhuma dance, stilts, crane dance and so on; the representatives of folk opera and Quyi are Shandong Bangzi, Lunan Dagu,, JujubeBang, Liu Zi Opera, String Opera, Liang Jia Xian, Siping tune, Shandong Qinshu, Guzi Qu, Yugu Opera, Liu Qin Opera, Shandong Qingyin and so on; folk instrumental music includes soft bow Jinghu, Heze Guzheng, Lunan Suona and so on. The local music of southern Shandong Province also includes ritual music dedicated to Confucius and some popular religious music in southern Shandong Province.

Development and Application of MOOC in Southern Shandong Province. MOOC has become the focus of global attention, especially in the field of education. Governments, social groups and universities all over the world have paid great attention to the construction of MOOC, and launched many good online education platforms, such as Coursera (for-profit platform) created by Professor Daphne Koller and Professor Andrew Ng. of Stanford University in the United States, the edX platform (non profit platform), a MOOC service agency jointly funded by Harvard University and Massachusetts Institute of Technology, and Udacity (for-profit platform) co-founded by Sebastian Thrun, David Stavens and Michael Sokolskaya .

Tsinghua University of China announced its accession to edX on May 21st 2013, and in June of the same year, it organized the campus experts to build the project team to begin to build the Chinese 
platform-XuetangX based on the edX platform open source code. In august, 2013, two online courses, "History of Chinese Architecture" and "Principles of Circuits" were set up in Chinese universities and colleges on XuetangX, and in October, 2013, XuetangX was formally opened to the whole world.

The development of MOOC in southern Shandong Province is unstoppable, and the higher education institutions and government agencies shows strong enthusiasm for it. There are Qufu Normal University, Linyi University, Jining University, Heze University, Zaozhuang University, Rizhao University City and many other higher vocational and technical colleges. At present, these colleges and universities are actively participating in MOOC project, for example, in our Zaozhuang University, some teachers were sent to Jinan to participate in MOOC training in early 2015, and online course production competitions were held. In September 2017, part of the online curriculum was launched to complement the reform of the credit system.At the same time, many enterprises have also held out an olive branch to MOOC, actively invested a variety of human and material resources in it, for example, Youku, NetEase, yeeyan, Guokr and other well-known domestic websites, all rushed to join the MOOC, and collaborated with the internationally renowned MOOC platform to launch many online courses.

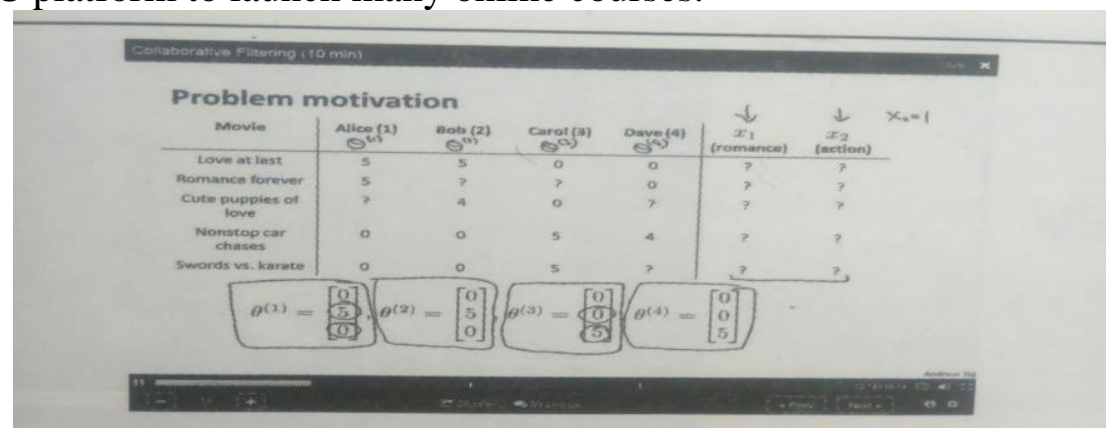

Figure 2. The online course

As far as I know, many primary and middle school students in the south of Shandong Province will now $\log$ on to the above-mentioned website for targeted learning, and these websites have become the auxiliary means for school learning.

The Present Situation of the Development of Local Music in Southern Shandong Province. Liu Qin Opera, also known as "La Hun Qiang ", is a representative local opera in southern Shandong Province. It has beautiful music, and its basic tune has developed from the Lunan folk minor keys, has the feature of high end rhyme. And free style according to the list is accepted within the basic tunes, so Liu Qin Opera has a great arbitrariness. Its formation can be traced back to the middle of the Qing Dynasty, before the formation of Beijing Opera. At first it is a means of begging, slowly became diverse, enriched and colorful, it could display a story, and then the beggars had become folk artists. After the founding of the People's Republic of China, under the guidance of literary and artistic policy of "letting a hundred flowers bloom" of the Communist Party of China, Liu Qin Opera, like other local music in southern Shandong Province, developed well. I remember when I was a child, my home was near the Liu Qin Opera Troupe in Zaozhuang City. Every morning I woke up from the percussion of the drums and the tune of the practice, and I would mischievously follow the tune, hummed the familiar tune, "Liu Qin Opera", on the way to school. When it comes to weekends or holidays, I will follow my parents into the theatre. I remembered there were " Shu Guan", "Lan Ma", Tongtai War and other historical stories, there were also modern plays such as "Eating Noodles in Soup". Most of these tell the stories of the ordinary families and come from life. Local music also has a very strong mass base in the countryside, and will be displayed for some marriage and funeral matters.

With the development of society, people moved from the bungalow into the building, theatres and troupes have gradually faded in their minds, replaced by some shoddy "blockbuster", television is full of boring entertainment programs. People's understanding of art and vulgarity has been distorted. Many of the best performers in Liu Qin Opera have changed careers. Even one of the 
most important accompaniment instruments in Liu Qin Qpera, folk lute in the movie Railway Guerrillas, , was also sent into the history museum, its crisp, pure voice is no less than any musical instrument, still in my ears. Many local music and plays are obviously regional, including language, but now many primary and middle school students seldom speak dialects, which is also one of the reasons that affect the development of local music. How to protect and inherit our local culture? A few years later, do we still have dialects and our own music in southern Shandong Province? Like other music in southern Shandong Province, Liu Qin Opera has a worrying future.

Better Inheritance and Development of Local Music in Southern Shandong Province. Establishing a unified "sharing education". Now the popular "sharing economy" mode can give us an inspiration, that is to say, a unified MOOC platform and university linkage mechanism can be established. There are many colleges and universities in the south of Shandong Province, all of them want to play an important role in the field of MOOC. Zaozhuang College, for example, encourages teachers to create online courses, conduct course competitions, which serve as standards to evaluate titles for teachers. Therefore, teachers are highly motivated. However, now the phenomenon that local colleges and universities are engaged in their own MOOC project independently is common, and there is no unified MOOC platform, there are a variety of courses, but there is no unified standard. Because of the different talent training programs in each school, there are the complexity of the course selection and the limitations of the selected course, so there are not many courses that can really interest the college students. Now colleges and universities are catching up with the reform of credit system, if they can reach an agreement on the mutual recognition of credit in MOOC courses, and establish a unified MOOC platform, they will greatly raise the enthusiasm of students to learn, and the course selection will also be more convenient. Music and Dance College of Zaozhuang University has introduced local music appreciation on Zaozhuang Liu Qin Opera and other courses in the talent training program revision.

But these course are only open to the students of a secondary college, if these course can be open to the entire school students, national and even global college students through the MOOC platform, it will be conducive to college students to obtain more elective courses credits, and even more conducive to the exchange and promotion of local music culture.

Getting wider audience.It is an era with highly developed digital media, and it can be said to be the age of Internet access to all people, network content can be accessible even on television. I believe our local music culture is more attractive to us than boring TV dramas and shoddy entertainment. Through the MOOC platform we can make and upload "Lunan local music" courses and make local education television stations, music opera channels, websites open to the public for free, so that more people can understand and love local music in Southern Shandong Province.

The transformation of the way of inheritance. The traditional way of inheriting music in southern Shandong Province is mainly oral teaching, most of relationships are teacher-student relationship and kinship. This way of inheritance has seriously restricted the development of local music, and has not kept up with the pace of the times, so we should carry forward the local music of southern Shandong Province through modern teaching methods. For example, making a "Liu Qin performance" MOOC course open to the public for free or with a low threshold, can make this classic musical instrument get back to our real life with its youth and vitality from the history museum. Displaying traditional music culture by the way of a MOOC course does not mean that every educatee has to be trained as an artist and connoisseur, but is to make the local music to get the broader inheritance through this new education method and idea of the MOOC platform.

Innovation of music and repertoire. There are many works of local music in southern Shandong Province. In addition to retaining classical music and repertoire and sharing these relevant materials to everyone through the MOOC platform, we should also innovate and create more music and repertoire with a sense of the times. Through the development of MOOC courses, we can set up study groups for discussion and analysis, can use the form of homework or tests, exams to raise the enthusiasm of everyone to create. In addition, because the cultural geography customs and music culture in southern Shandong Province a lot of similarities, they are relatively easy to merge together. Through the mode of "sharing education", gathering the advantages of music culture in all 
regions of southern Shandong Province together, just in the way in which the "four big Anhui troupes" merged to form Beijing Opera, changing the scattered pattern, forming a music culture with the characteristics of southern Shandong Province, so that the local music in southern Shandong Province can get a better development.

Government support. Under the guidance and support of the policy of the Central Committee of the Communist Party of China on literature and art, we should train a group of outstanding local music and cultural talents to create good works, and make due contributions to the development of local economy and the prosperity of local culture. At present, the development of various regions in southern Shandong Province is closely related to culture, which also includes music culture, and it is a good time for the local music in southern Shandong Province to play its role. Take the Taierzhuang ancient city tourist attractions project for an example, people want to see the ruins, but they are more eager to see cultural heritage, folk culture, regional culture, music culture, etc.,, so we can train talents for scenic spots through MOOC education, which can not only solve the problem of employment, enrich the tourist culture of the ancient city, but also let more people see the unique charm of local music in southern Shandong Province.

\section{Conclusion}

By writing here, I feel that the contents involved in this paper are not enough, and I always have a sense of haste. The modern education method cannot be said to the only method to promote local music, but it is also an effective method. Next, I will work with my colleagues and students to develop a free online course, which is called "the Appreciation of Local Music in Southern Shandong Province". I will continue to follow this road of combination of new technology and traditional music culture, and carry out in-depth exploration and research, to let our local music go out of the home and walk up to the world.

\section{Acknowledgement}

This work is supported by Shandong provincial art education project (No.YJ201612093); Education reform program of Zaozhuang University (No. YJG16028).

\section{Reference}

[1] Information on http://blog.sina.com.cn

[2] J.Haber: Massive Open Online Courses (China Renmin University Press, China 2015).

[3] J.L. Jiao and P.Wang: MOOC-The Learning Revolution in Internet + Education Age(China Machine Press, China 2016).

[4] J.N.Sun and Z.Q.Zhou: Chinese Music History Compendium (Shandong Education Press, China 1993).

[5] Y.Li: History of Traditional Music in Southern Shandong Province(Soochow University Press, China 2014).

[6] P.P.Kong: From La Hun Qiang to Liu Qin Opera, (Ph.D.,Chinese National Academy of Art, China 2007), p.31.

[7] H.X.Xu: Art Education, (2009) No.12, p.92.

[8] L.Li: Reading Notes of Music(Shanxi Education Press, China 1990) .

[9] W.X.Qi: Higher Education(Shandong University Press, China 2010). 